\title{
ARTICLE - PHYSICAL EDUCATION, GYMNASTICS, GAMES AND SPORTS IN BRAZIL - THE GERMAN IMPACT
}

LOTHAR WIESER ${ }^{\prime}$

ORCID: https://orcid.org/0000-0001-6188-6683

MICHAEL KRÜGER"

ORCID: https://orcid.org/0000-0002-4996-7859

I Institut für Sportgeschichte, Hannover and Baden-Württemberg.

II Westfälische Wilhelms-Universty of Münster, Westfalen, Germany.

\begin{abstract}
This contribution for the dossier Education, health and recreation: historical processes of body education in the Brazilian journal Educaşão em Revista is based on a long tradition of research in the history of physical education and sport in Germany with respect to the $19^{\text {th }}$ and $20^{\text {th }}$ century. Next to the Swedish model of gymnastics and body education, the German movement of Turnen and gymnastics was very influential and sustainable for the introduction of concepts of systematic body education worldwide. Brazil is one of numerous countries and nations adopting relevant parts of the German body concept of Turnen and gymnastics. There at least two reasons for this process of cultural transfer and transformation. Firstly, the German emigrants who implemented their body experiences including their cultural traditions in their new home countries, and secondly, the elaborate system of didactics and methodic of German gymnastics which were easy to transfer to the educational institutions. This also happened in Brazil.
\end{abstract}

Keywords: Turnen. Gymnastics. Cultural transfer. German emigration.

Lothar Wieser - Dr. disc. pol. by Universität Göttingen. Physical Education teacher. Researcher at the Institut für Sportgeschichte, Hannover and Institut für Sportgeschichte Baden-Württemberg, Maulbronn. E-Mail:<lothar.wieser@web.de>.

Michael Krüger - Doctor in History Studies by University of Tuebingen/Germany, Professor at the Westfälische Wilhelms-University of Miuenster/Wesrf./Germany. E-Mail:<mkrueger@uni-muenster > . https://www.uni-muenster.de/Sportwissenschaft/Paedagogik/index.html 


\section{EDUCACְ̃̃O FíSICA, GINÁSTICA, JOGOS E ESPORTE NO BRASIL: O IMPACTO ALEMÃO}

RESUMO: Esta contribuição para o dossiê Educação, saúde e recreação: processos históricos da educação do corpo é baseada na longa tradição de pesquisa em história da educação física e do esporte na Alemanha, a respeito dos séculos XIX e XX. Assim como modelo sueco de ginástica e educação do corpo, o movimento alemão do Turnen e ginástica foi muito influente e sustentável para a introdução dos conceitos de educação sistemática do corpo pelo mundo. O Brasil é um dos numerosos países e nações que adotaram partes relevantes do conceito alemão de corpo do Turnen e da ginástica. Há pelo menos duas razões para esse processo de transferência cultural e transformação. Em primeiro lugar, os emigrantes alemães que implementaram suas experiências corporais incluindo suas tradições culturais em suas novas pátrias, e, além disso, o elaborado sistema de didática e metódica da ginástica alemã, que era fácil de transferir para instituições educativas. Isso também aconteceu no Brasil.

Palavras-chave:Turnen. Ginástica. Transferência cultural. Emigração alemã.

\section{INTRODUCTION}

This paper is based on Lothar Wieser's work on German Gymnastics in Brazil, published in 1990. Original documents and sources of both German and Brazil archives of Turner Clubs could be found and interpreted for a better understanding of the German impact on the development of Brazilian sports development since the $19^{\text {th }}$ century. Additionally, contemporary reports in both German and Brazilian papers and books on German gymnastics and sports in Brazil completed the thesis of Wieser's dissertation of the influence of German immigrants in Brazil. Among others, we will especially mention the work of Leomar Tesche and Evelise Quitzau who successfully continue the work on the history of physical education and sports in Brazil influenced by German traditions.

For this paper, additional sources and literature until the end of World War II were used to show the changing impact of Germans on Brazil depending on mainly political and social contexts. Actually, the Atlas do Esporte no Rio Grande do Sul and the Atlas do Esporte no Brasilare both very important research projects of Brazilian historians including numerous references of the impact of German immigrants on Brazilian sports and games. 
The paper focusses on the first periods of German immigration to Brazil. It is divided chronologically in a major part including the German Turners' movement and their impact in Brazil. Without further explanation of who the German Turner's were and what kind of body culture they were practicing and living, their cultural import in Brazil could not be sufficiently understood. Further steps of the development include the impact of play and games during the 1920s and 1930s, and then, the period since 1935 until the early 1950s when World War II was finished. A new, post-war world order was established in which both Germanies, East and West Germany, and Brazil were compelled to play their specific role in the process of globalization. Physical education and sports are part of it. At the end of the paper, we present a chronological schema with relevant events and processes in sport and physical education in Brazil and Germany.

Actually, German roots in Brazilian sports culture can still be found. However, they are overlapped by Portuguese, Anglo-Saxon and universal patterns of sports culture and physical education. The history of physical education and sports in Brazil is closely linked with the history of migration in general and especially of immigration from various parts of the world to the former Portuguese Colony and later the brazilian Empire until to the current Federal Republic of Brazil.

\section{IMMIGRATION AND CULTURAL TRANSFER}

During various waves of immigration since the early $19^{\text {th }}$ century, German immigrants played a major role in the process of nation-building of Brazil, with respect to body culture, play and games.

Germans were part of the first colonists and mercenaries immigrating to the southern regions of Brazil, today belonging to the states Rio Grande do Sul, Santa Catarina, and Paraná. Trading companies run their offices in the major harbor cities. The range of transatlantic trade between Europe and both the Northern and Southern parts of the American continent grew constantly and rapidly.

The early German immigrants carried in their luggage both their individual abilities in education, work and craft, and what we may call their culture, in general. It included next to language, religion, customs, morals and a specific "habitus" of gymnastics, games and sports, too. The first settlers in Rio do Sul, in southern Santa Catarina and in the hinterland of São Paulo were mostly hailed from rural areas of South West Germany. However, there is 
no proof of any relation to the early Turner movement in Germany, initiated by Friedrich Ludwig Jahn in Berlin. These Turners were mostly students and educated young boys and citizens whereas the first German settlers in Brazil were traders, peasants and craftsmen looking for work and a better life abroad. It took some decades, until the 1850s that a second group of German immigrants settled in Brazil. These members of the so-called "Legion of Germans" (Deutsche Legion) of 1851 also founded the first German Turnverein and the gun club (Schützenverein) in Porto Alegre, facts which are clearly documented by proved sources. A respectable number of former participants of the German revolution of 1848/49 were among the about 2000 persons of this group. After the defeat of the revolution in Germany and Europe, many of them were persecuted. They looked for asylum and went into exile abroad, mostly to the USA but to other European countries like France, Switzerland and England as well, and, finally, to South America, Australia and Brazil, too. This group of exiled Germans in Brazil were historized as the "leaven (or yeast) of the colonies" due to their high education, their abilities and activities with respect to their role in society and politics in Brazil (Koseritz' Kalender 1874, p. 116).

German immigrants hailing from Saxony, founded the first German Turnverein (turner club) in Brazil at all in Santa Catarina, today Joinville, in 1858. Some of them had participated at the German revolution. They were called "fourtyeighters" (1848er). A year later, in 1859, another Turnverein was founded in Rio de Janeiro, the since capital of Brazil. It was initiated by clerks and officers of the trading companies in Rio. A few years later, in 1864, the foundation of a turner club in Porto Alegre is reported. Even in the jungle of Brazil, in Espirito Santo, German gymnastics could be established in 1876. It took some more decades that new clubs for sports and games completed the broader culture of physical education and sports in Brazil during the $20^{\text {th }}$ century.

It is worth mentioning that the typical concept of a German Verein (club) was not just a club for sports, games, and fun, but included a social, cultural, and political idea of independent, free, and self-conscious citizens for a democratic and human society and politics. In Brazil, the German clubs were useful for their members and the community to survive in strange and wild surroundings. In common with schools and Christian communities, the clubs supported the process of integration and identity that means the building of a common we-feeling of both as Germans in Brazil and as Brazilians of German cultural heritage. 


\section{THE CULTURE OF GERMAN TURNEN - A SHORT EXPLANATION}

The German-Brazilian Turner relied on the German "father of Gymnastics (Turnen)", Friedrich Ludwig Jahn (1778-1852). He is regarded as the founder of the Turner-movement which was in fact a middle-class movement in Germany since the end of the $18^{\text {th }}$ century longing until the $20^{\text {th }}$ century. Turnen was just another, German word for gymnastics. The philanthropic educator Johann Christoph Friedrich GutsMuths (1752-1839) had claimed to re-invent the ancient Greek culture of gymnastics and athletics for modern educational purposes. His book "Gymnastics for youth" should contribute to a better, harmonious education of enlightened "citoyens" being able to build communities by their own will, means and communication, as Jean Jacques Rousseau (1712-1778), the crucial scholar of the European age of enlightenment, had described and conceptualized in his work "Le contrat social" (1762). This concept of an enlightened education of body and mind was regarded as a precondition for a modern nation state, governed not any more by aristocratic elites but by educated men selected for their abilities, strength, achievement, and performance.

Whereas philosophers and educators like Rousseau and GutsMuths regarded gymnastics as a general or universal means of the education of youth, the Turnvater Jahn changed this concept to a concept of national education of Germans. By contrast to gymnastics, he invented the German notion of Turnen to express that this German gymnastic was not universal but German, old customs of specific German body exercises and games, as he asserted in his work "Die Deutsche Turnkunst" (The German Art of Gymnastics), published in 1816. This book included both his national ideology of cultural bonds of native Germans - he called it "Deutsches Volkstum" (German Peoples' Nationalism) - and the practical experiences of Turnen or gymnastics of young boys at the famous first German gymnastics place in Berlin opened in 1811. In a wider sense, the "Deutsches Volksthum" even was a kind of utopic constitution of the German people, bound together by common rules, cultural traditions, and wefeelings. Turnen was just one means to constitute this concept.

Jahn wanted to contribute to the process of nation-building in Germany with his work. You should keep in mind that, at that time, Germany was divided in many small and independent countries except that of Prussia in the north and Austria in the south of central Europe. However, Germans lived everywhere in Europe, and even abroad. Therefore, Jahn believed that his German concept of 
gymnastics should fit and appeal all Germans everywhere, even those who had to emigrate on various parts of the globe, also to South America and Brazil, for sure. Turnen should serve as a means to unite all Germans by a common body culture.

Jahn himself could not experience the realization of his national dream, the building of a German nation state. He died in 1852, and the German empire was founded in 1870/71 after a range of so-called national wars of unification. In Brazil, the process of nationbuilding run very different from Germany but both processes were influenced by the French revolution and the military expansion of the French emperor Napoleon. He had defeated both the German states and Portugal which lead to the rise of a German national movement including the Turner movement in Germany, and to the end of the colonial empire of Portugal. In 1822, Brazil became an independent empire (Kaiserreich). Shortly after, Germans immigrated to Brazil.

Following generations of Germans carried the cultural burden of German gymnastics including both body exercises and games, and other subjects of education like education of rationality and truth, humanity and self-consciousness. In addition, learning of the first language (mother tongue), reading of good books, knowledge of the rights and duties of humans, knowledge of the laws and the constitutions of societies, history of the fatherland, learning of practical arts and crafts, singing and fine arts.

"They should learn everything", claimed Jahn respecting body exercises: "Walking, running, jumping, throwing, carrying are exercises for free and everybody and everywhere, for free like air. The state can expect these exercises by both poor, middle class, and rich. Everybody is in need of them. Climbing, escalating, balancing are useful and easy to practice as well. The state has no expenses because they can be practiced everywhere, by no means only in the mountains. Swimming ought to become a crucial art in Germany, a country which is famous to its many and beautiful rivers and lakes." (Jahn 1928, p. 243).

In common with his contemporary fellow GutsMuths, Jahn recommend a wide range of additional bodily exercise and mostly traditional games including rowing, fencing, sailing, skating, and shooting. All these exercises and games were by no means reserved for young boys and men, but women and girls should also participate in gymnastics;at least, certainly in those relating to the contemporary cultural and; at moral concept of gendering. Actually, dancing and healthy gymnastics seemed to be more adequate for girls and women than heavy athletics and apparatus gymnastics. 
Little by little gymnastics became the most relevant concept of physical education for girls and women during the $19^{\text {th }}$ and $20^{\text {th }}$ century. The German Gymnastics Association is the worlds' greatest national institution for women's sports at all. This development was related to the process of popularization and schoolization of gymnastics, initiated by the German Gymnastics clubs since the German revolution of 1848 and, finally, the constitution of the national German Gymnastics Association in 1860/68. This organization became both a mass organization of the national body culture named Turnen, and a lobbyist for the responsibility of the upcoming German nation state to include body exercises and finally play and games, in the institutions of public education. At least, this policy was successful. Play, games, gymnastics, and sports are both the most popular activities of German youth in their free and leisure mostly in clubs (Turn-und Sportvereine), and physical education, movement, and sport are obligatory for every pupil at every school in Germany.

Allgroups of Germans immigrating to Brazil carried gymnastics in their cultural luggage, however, a diverse luggage depending from the particular period, fashion, and habitus. For sure, there were also respectable differences of social classes and regions, the immigrants came from. The impact of the German workers gymnastics and sports movement can be detected in documents of former gymnastics clubs just as documents and symbols of the middle-class turner movement. For example, the Craftsmen Support Association (now Sociedade Rio Branco) founded a gymnastics section in Curitiba. Sports clubs with the name "Vorwärts" are certainly assigned to the workers' movement. (Koseritz' Deutsche Zeitung, Porto Alegre, Nr. 1, 3. 1. 1893, p. 3).

The influence of Jahn remained strong over decades. Images of him, sculptures and monuments, his symbols - the 4 Fs (frisch, fromm, fröhlich, frei) ${ }^{1}$ can be found in the archives of every former German Turnverein in Brazil.

\section{GERMAN GYMNASTICS AND THE BEGINNING OF SPORTS MOVEMENT IN BRAZIL}

Like in Germany, the gymnastics movement just as the sports movement in Brazil were a phenomenon of the growing cities or a result of the urbanization of Brazil. The first German gymnastics clubs were located in Joinville (1858), Rio de Janeiro (1859), and Porto Alegre (1863). 
However, there are some rural areas in Brazil without Turner Clubs: Nova Friburgo close to Rio de Janeiro (since 1818), São Leopoldo in Rio Grande do Sul (1824), Tres Forquilhas and São Pedro de Alcântara near Torres, Rio Grande do Sul (1826), São Pedro de Alcântara in southern Santa Catarina (1829), Rio Negro, then situated the south west area of the province of São Paulo, today named Paraná (1829). In these rural areas of the first wave of immigrants founded by German farmers the existence of Turner Clubs could not be proved.

The life in these areas was hard and coined by the rhythm of nature with clearing the jungle, sowing, and harvesting - depending from climate and the mood of the weather. There was no or at least little time for leisure and fun. Like in Germany and other parts of the rural world, Christian festivals, customs and traditions like the "Kirchweihfeste" (Kerb) were the only and rare opportunities to play and dance. The German or European bowling - kegeln - was certainly practiced during these festivals as well.

Similar to Germany, the take-off German Turner Clubs in Brazil took place in the 1860s when both the German national movement and the turner movement were strongly motivated by the ceremonies for the 100st birthday of the "poet of liberty" Friedrich Schiller, the hero of the educated German middle class (Bildungsbürgertum). The period of the 1860 s, before the constitution of the German empire, was a politically extremely excited decade. Simultaneously, in the USA the Civil War was forthcoming. Finally, in Brazil a conflict with the neighborhood state Paraguay in the Southwest of the country led to bloody war in 1865.

The Festschrift of the $50^{\text {th }}$ centenary of the Turnverein in Joinville mentions both occurences: "When the Confederates opened the American brother war in 1861, April $12^{\text {th }}$ by the cannonade of Fort Sumter in the harbor of Charleston, German Turners came together under the star-spangled banner to fight against slavery. The basis of a nation state must not be the slavery of negroes but justice and liberty". (Festschrift, Joinville 1908, p. 11).

We should keep in mind that Brazil was the world's greatest state based on slavery at that time. Therefore, the opinion and attitude of the German Turners in Brazil was obviously completely against the doctrine of slavery in Brazil. In addition, the author of the Festschrift compares the American Civil War to the Brazilian-Paraguayan War of 1865: "The Turners in Joinville proved their sense for justice, liberty, and fatherland by fighting for their Brazilian homeland. They followed the call 'volunteers to the front'. German Turners, young 
boys served their new homeland passionately and voluntarily. They took their weapons and marched to the battlefield fighting for the honor of Brazil.” (Festschrift, Joinville 1908, p. 11).

Like the Turners in Joinville, other German immigrants organized in Clubs, followed this example, namely the in Blumenau and Porto Alegre.

The German Turners in Brazil were highly interested in information about the events in Germany. They intensively communicated both with each other in Brazil and with their friends and relatives in Germany. The papers in Brazil which were edited and read by German immigrants, for example the colony-paper (Kolonie-Zeitung) in Joinville, reported detailed of all relevant events in Germany. In 1865, even a speech of the German revolutionist Karl Blind, former member of the Turner Club of Mannheim, giving in his exile in London, was printed and could be studied in Brazil. Blind spoke at a Turnfest in London, organized by the famous German Turnverein in the British capital, which was in fact both a meeting place for German immigrants and the initial institution for an international gymnastics and sports movement through organizing international festivals in the Cristal palace. For sure, the major political events were broadly reported, the German brotherwar of 1866 and the Franco-Prussian War of 1870/71 resulting with the inauguration of the German emperor and the first German Empire in Versailles 1871. The former German revolutionist, Turner and immigrant in Joinville, Carl Parucker, took the chance to a toast for both the German emperor Kaiser Wilhelm, and the Brazilian emperor Pedro II. whose troops had just defeated Paraguay after a long and bloody war. (Festschrift, Joinville 1908, p. 15).

Sport in the modern sense can only be spoken with the founding of the first rifle, rider and rowing clubs. The well-known journalist Karl von Koseritz reported in 1864 to the appearing in Gotha Allgemeine Auswanderungszeitung of gymnastics and shooting clubs in Rio Grande do Sul. (19 (1864) no. 14, 31.3.). In the Itajaí Valley of Santa Catarina, it was from 1874 to found numerous shooting clubs, as well as in Santa Cruz do Sul, Rio Grande do Sul, where many riders clubs are detectable. (Petry, 1982, Hundert Jahre Deutschtum 1924, 336 ff.). The first artificial swimming pool in Brazil was built by the German Turnverein in 1885 in Porto Alegre as a floating wooden structure in the Rio Guaíba. In 1888 gymnastic members founded the first rowing club in Porto Alegre. Among the members of this club are also the founders of the cycling club "Blitz" and the first Naturbeilverein. (Wieser 1990, passim). 
The Turnverein in Porto Alegre, officially founded in 1867 and the Turn Club, founded in 1887, merged into the Turnerbund Porto Alegre. Over a long period of time, the Turnerbund was the most important driving force of German turnerism in Rio Grande do Sul. It was a pushing force for the rise of turnerism in Rio Grande do Sul and furthermore. Cooperating with other German Turner Clubs in São Leopoldo, Lomba Grande, Novo Hamburgo, Santa Cruz and Campo Bom they founded the German Gymnastics Association (Deutsche Turnerschaft von Rio Grande do Sul) in Porto Alegre in 1895. The development of the Turnerbund exemplifies the genesis of gymnastics and sports in the southern areas of Brazil.

Two persons stand for this development: Jacob Aloys Friederichs, a Prussian, born and growing up in the little town of Merl, located at the river of Mosel, an affluent of the Rhine river. Friederichs propagated and organized Germanism (Deutschtum) and Turnerism (Turnertum) in Rio Grande do Sul which were both sides of the coin. The other key person is Georg Black. He came from Munich and immigrated to Brazil in 1902. Black had a certificate as proved gymnastics teacher from Munich. He was responsible for the distribution of gymnastics as practical body exercises in turner halls and places in Brazil, mainly in Rio Grande do Sul.

About 1900 and later, economy, industry, and the wealth of the nation were increasing strongly. In Germany, a wealthy middle class grew up which constituted the social fundament for the rise of gymnastics, games and sports as a culture of the majority of the crowd including middle classes and the common people. Similar developments happened in Brazil, however, at that time gymnastics, games and sports were by no means mass-phenomena. The middle classes of the urban metropoles of Brazil like Curitiba, São Paulo and Rio de Janeiro had reached respectable wealth. Among them were many citizens with a background of German migration. (Delhaes-Guenther 1973, passim).

These relatively wealthy urban middle classes, in German städtisches Bürgertum, were mainly responsible for practicing and propagating the new trends and fashions of gymnastics, games and sports from Europe and the USA in Brazil. The gymnastics Clubs were the institutional, social, and local space to do that.

In consequence, the German gymnastics clubs modernized their program and practice of games and exercises based on the traditional concept Jahn's Turnkunst, which initially emanated from 
the investment of gymnastics. In addition to exercises on home-made devices was also played on them. Therefore, playgrounds are always to be found at the (later) built gymnasiums.

Regarding the equipment of the turner halls and the textbooks collected in the club's libraries, this process of modernization can be proved little by little. In 1890, the Turners of Rio de Janeiro ordered new apparatus, a noble high bar (Salonreck), a pommel horse and a horse for vaulting, a chest for leapfrogging, and iron apparatus for high jumping. The turner halls filled with both traditional gymnastics apparatus, apparatus for Swedish gymnastics like wooden benches and wall bars, and, finally, equipment for athletics, not mentioned various balls for sporting ball games. On occasion of the inauguration of its new Turner hall, the Turnerbund in Porto Alegre ordered the complete equipment of a modern Turner hall from the company for gymnastics and sports apparatus Fechner in Leipzig/Saxonia. Part of the order were also balls, including footballs, which suggests that football was from about 1895 to the repertoire of "Turnspiele" belonged.

A similar development can be proved respecting the list of inventory content of the Turner Club in Blumenau. The clubs were subscribers of the German Turner-and increasing sports press, especially the Deutsche Turn Zeitung representing the most relevant trends and fashions in gymnastics and sports. In addition, every club collected in their libraries reference and specialized book for teaching gymnastics, sports, and physical education from Germany. Actually, the Brazilian Turners and sportsmen were informed with current debates on physical education, concepts training, didactics and methodic of physical education and sports. For sure, this kind of gymnastics eighty or hundred years ago was completely different from modern artistic gymnastics today. Free-standing exercises of a mass of Turners equipped with bars or bar bells, human pyramids, throwing with stones, games like the German Barlauf or Tambourinball are not practiced any more but were then popular both in German and Brazilian Turner Clubs and at schools. Other games like punhobol (faustbol) and especially handebol are still played today.

Contacts to and communication with Europe and Germany were not only possible to realize by papers and books but by voyages to turner festivals in Germany too. Since 1898, Brazilian Turners from various clubs visited the huge Deutsche Turnfeste (Turner festivals) including ten- and sometimes hundreds of thousands participants and guests, not only from all parts of Germany but of all parts of the world where Germans and German Turners had emigrated. 
The above mentioned banner of the Turnerbund in Porto Alegre was dedicated at the German Turnfest in Nuremberg in 1903 where Jacob Aloys Friederichs got to know personally the chairman of the Deutsche Turnerschaft, the then greatest gymnastics and sports organization worldwide, Dr. Ferdinand Goetz from Leipzig. Both remained livelong friends. Goetz is the only Chairman of German Turners who was honored in Porto Alegre a monument. When Georg Black had visited the Turnfest in Leipzig in 1913 and afterwards his native town Munich, he got the idea to initiate a group of boy scouts (Pfadfinder) in Porto Alegre.

The Turnerbund in Porto Alegre experienced a very positive development. In 1895 a new turner hall was built, however, due to the rapidly increasing number of members, only a few years later proved to be too small. In consequence, the Porto Alegre Turners decided to build a new turner hall and turner house. The chairs wanted the "German house" to be more than just a turner hall but a communication Centre for all Germans and German-Brazilians including a theatre, library and exercising rooms for actors and musicians. Similar to the great Turner Clubs in USA and Germany, the Porto Alegre Turners had a wider sense of Turnen and Turnverein as a space for culture and arts for spending free time together with friends and like-minded persons.

The Turner Clubs considered themselves as cultural societies in a wider sense. Jacob Aloys Friederichs in 1898 founded a library, which in the Turnerbund (Sociedade de Ginástica Porto Alegre) still carries his name. He propagated the culture of music and theatre in the Club and initiated a Sängerriege - a chorus of Turners. In 1906, he prescribed a contest for a song to "praise Brazil" an occasion of the Turnfest. The result was the "song of the German Brazilians" (Messele-Wieser 1993, p. 8). In 1922, he collected "Germans Songs" for Turnvereine in Brazil. By doing this, he intended to strengthen both "Germanism" (Deutsches Volkstum) and respect to the "new homeland Brazil" (Liederbuch 1922). However, the First World War destroyed the ambitious visions of the German House.

\section{GYMNASTICS AND SPORTS UNITED IN THE CLUB OF PORTO ALEGRE}

Turnen was more than apparatus gymnastics and free-stand exercises. It also included games and sports. The turners were open for new developments of physical culture and leisure activities. 
Rowing and cycling and sports games, especially football became parts of the program and content of the Club in Porto Alegre. When the football team of Rio Grande had visited Porto Alegre for a show game in 1903, the Turnverein had invited the team in common with other clubs in Porto Alegre like the Schütrenverein (shooting club), the rowing club and the rowing club "Germania", the cycling club "Blitz" and a club for naturopathy. The papers reported excitingly of the "real people's event". The teams of Rio Grande, $200 \mathrm{~km}$ away from Porto Alegre, showed how to play football "correctly", because other clubs for physical exercises in Porto Alegre, especially the turners, wanted to introduce football in their program. The event was organized like a Turnfest including a Festrug (procession) to the race court of the cycling club where the match took place in the morning of September $7^{\text {th }}$, 1903 At the previous evening, the teams were invited to a traditional ceremony drinking session in the Turnerbund. The show match was played between the two teams of Rio Grande. In another match against a mixed team of Porto Alegre, the footballers of Rio Grande won 9:2. This fact makes clear that the athletes of Porto Alegre still did not know sufficiently how to play the game of football.

"The Porto Alegre Turners had the thankful opportunity", could be read in a contemporary report, "to demonstrate a gymnastics performance to the honorary guests of Rio Grande on the occasion of the ceremonial dinner in the turner hall. Our gymnasts proved their abilities in an extremely impressive manner. We Turners wish and hope for the Sports Club Rio Grande and the actually initiated Football Club Porto Alegre, connected with the cycling Club "Blitz" and the "Gremio Football Porto Alegrense" a happy and positively growing development." (Jahresbericht des Turnerbundes Porto Alegre über das Jahr 1903)

Both mentioned Clubs were officially founded one week after this event on September $15^{\text {th }}$ by Germans. Therefore, the assertion may be allowed that Germans and German Turners were among those people who had invented Brazilian football. Brazil became the world's leading nation for football, a position the Brazilian footballers could sustain at least until the World Championship in Brazil 2014.

There is a lot of evidence in the historical documents and journals that the Porto Alegre Turners were very open and offensive in reforming the traditional concept of gymnastics with new and modern forms and manners of games and sports including football. Their self-image as lobbyists for body culture and body exercises 
motivated the turners to propagate any sort of sports, games and gymnastics for all people of any social class and birth. Politically, they voted for new pitches and sports halls. J. Aloys Friederichs succeeded in pushing the project to build a new and greater pitch on a free ground of the suburb of São João. The pitch was dedicated officially on May 21 $1^{\text {st }}, 1911$, on occasion of the 100st anniversary of the opening of the famous Hasenheide Turnplatz of Jahn in Berlin. Like the Hasenheide, the playground should become both, a space for play, games and exercises for youth, and a place for excursion on weekends for families with their children of Porto Alegre. Voluntary coaches for games (Spielwarte) were chosen in the Turnverein. They should instruct the youth in playing the games (Turn- und Rasenspiele) and doing athletic exercises (volkstümliche Übungen).

As mentioned above, chairman Friederichs and professor Black had visited Germany in 1913 for the Turner Festival in Leipzig. Georg Black used the opportunity to get to know the new trends in sports games and athletics. He was one of the first four graduates of the "Sports Order" for "versatile performance in the field of physical education" founded by the German Reich Committee for the Olympic Games. The award was first presented in 1913 on the occasion of the "First Berlin Youth Game Festival in the German Stadium". Black, who was a member of the Turner Federation Porto Alegre and the gymnastics club Munich, received the badge in gold, since he had already passed the age of 32 years. (Badische Neueste Nachrichten, Mannheim, 9. 9. 1913). The "Sports Order" exists until today as a "German Sports Badge".

Gymnast Black has introduced the new experiences to his work as a gymnastics instructor at Porto Alegres Schools and clubs in the Rio Grande do Sul Gymnastics Federation. As a good athlete, he was one of the first players of Grêmio Football Porto Alegre, founded the football team "Frisch Auf" in the Turnerbund. The Frisch Auf was section of the Turnerbund, brought Tambourinball and fistball to southern Brazil and led in 1913 the first patrol of Brazilian Scouts. At his suggestion, the Turnerfechten was reactivated, which experienced a considerable boom in the twenties under the leadership of Ferdinand Fenchel. On Black founds a whole gymnastics dynasty, which persists to this day. (Mazo 2010, Wieser 2013).

During his stay in Germany, J. Aloys Friederichs gave a speech to the German-South American Society in Berlin (Süd-und Mittelamerika 7 1914, p. 20). In Brazil, the German Turners had intensively studied 
the German journals on gymnastics and sports, especially those of the "games movement", edited by the Zentralausschuss für Volks- und Jugendspiele (Central Committee for Youth- and People's Games). Therefore, the Brazilian Turners were also motivated "to keep up with modern times" corresponding with needs and interests of youth. In consequence, new pitches and playgrounds were initiated, and the Brazilian Turner Clubs were developing to clubs for multiple sports, gymnastics, and physical activities. By the way, this development took place both in Germany and in Brazil.

\section{HIGHLIGHTS OF SPORTS IN THE 1920S AND 1930S}

During the 1920s and 1930s, the positive development of gymnastics, games and sports kept on. New clubs were founded everywhere in Brazil even in the binterland (back country) and rural areas of Brazil. The number of members in the clubs increased, new sports were introduced, including national leagues and associations, the organizational structure of sports live could be improved, physical education at schools and in clubs became more or less matters of course.

Two crucial highlights coined the sports development, too: Firstly, the celebrations of the $100^{\text {th }}$ centenary of the independence of Brazil in 1922, and, secondly, of the German immigration in 1924. Both events were adequate occasions for German-Brazilian gymnasts, sport, and athletes to confess their affiliation to Brazil. They demonstrated that they were ready to strengthen their body for the wealth, development, and defense of their new homeland.

In 1922, the "Olympic contests of Latin America" took place in Rio de Janeiro. The best athletes of Rio Grande do Sul were nominated by a "Mr. Frank Long". Three of the nine participants of Rio Grande were members of the Turnerbund Porto Alegre, four of the Turner Club São Leopoldo, and one of the Rowing Club Tamadare of Porto Alegre. The Brazilian athletes had to make qualifying for their participants at the games before they were allowed to start against athletes of Argentina and Chile. Willy Fick of the Turnverein Porto Alegre became Brazilian champion in pole vault mastering a height of 3,28 meters, and Tietzman reached 1,70 in high jump and the $3^{\text {rd }}$ place. Further members of the Turner Clubs were also successful: Brück: 800 meters (2min 10s), $3^{\text {rd }}$ place; Wolf: 100 meters $(11,2 \mathrm{~s}), 3^{\text {rd }}$ place; Seewald: javelin throw $(53,25 \mathrm{~m}), 1^{\text {st }}$ place.

All "Gaúchos" had reached the qualifying and finished among the best athletes. Willi Seewald finished first in javelin throw and became 
champion of South America, almost 6 meter in front of the second.

In 1924, the clubs of German colony were celebrating the 100st anniversary of German immigration in Brazil. The central event took place on the playground of the Turner Society of Porto Alegre. The festival topped all gymnastics festivals (Turnfeste) ever in Brazil, including championships in various contests and sports, athletics, combined and all-around contests, and, finally, a relay from Porto Alegre to São Leopoldo.

The head coach (Oberturnwart) of the Turnerschaft of Rio Grande do Sul, Georg Black, realized the idea of this special relay (Eilbotenlauf). Such relays were very popular in Germany, too. The most famous should become the Olympic torch relay as run at the Berlin Olympics 1936. The relay of the Turnerschaft of Rio Grande do Sul should include runners from Clubs along the route between Santa Cruz and Porto Alegre, ending at the monument of the German immigration in São Leopoldo. The relay should become a "symbol of unity" and confession for Brazil. Chairman Friederichs donated prizes for gymnasts and athletes consisting of wooden plates for gymnasts, singers, and shooters. (Festschrift 1929, p. 43).

Many participants of the Brazilian championships of athletics in 1926 in Rio de Janeiro were mainly members of the Turner Clubs. Guilherme Panitz of the Turner Club Porto Alegre finished first in long jump by reaching the then record for South America with 6, 69 meters. Brazilian delegations visited the huge Turner festivals in Munich 1923, Cologne 1928, Stuttgart 1933 and Breslau 1938. They were highly welcomed by their host in Germany. The children of Georg Black, Minna and Karl, were studying sports and physical education at the German University of Physical Exercises in Berlin, led by Carl Diem. Some Clubs asked for German coaches like Estrela (Leo Joas) and Santa Cruz do Sul (Richard Schmiedel). They gave further impulses for gymnastics and sports in Brazil.

In July 1927, Herbert Strauß, a gymnastics teacher and physical educator from Berlin, visited South America. ${ }^{2}$ The German Gymnastics Association (Deutsche Turnerschaft) and the "Club for Germanism abroad" (Verein für das Deutschtum im Ausland, VDA) supported him and his tour. Their common aim was to demonstrate the new German Turnen to schools and clubs. A special issue of the Turnzeitung of Rio de Janeiro reported of his visit in detail.

After World War I, a new "mental ribbon" between Germany and the German Clubs abroad should be bound, said Herbert Knipping, 
the German legate in Rio de Janeiro. The former chancellor Dr. Luther confirmed in a speech to German Gymnasts from Chile that Turnen in South America had functioned as a "ribbon interconnecting the people as a whole". The schoolmaster of the German school in Rio de Janeiro, Dr. Künzig, noted that the VDA as one of the representatives of the new Germanism had sent an ambassador in the person of gymnastics teacher Strauß. He declared that "the new German Turnen was related to the interests and motives of the current youth". The boys and girls were excited about that just as the teachers. Beyond the practice of gymnastics, games, and sports, the tour of Mr. Strauß would contribute to strengthening the bonds between Turnerism in Germany and Brazil (Turnverein Rio de Janeiro, 1927).

Herbert Strauß visited all major cities in the South of the continent. His initiative was highly appreciated by both German Gymnastics and Brazilian sports clubs. The Sportsclub Fluminense and the Yachting Club Brasileiro offered their playgrounds for the demonstration lessons of Strauß. In the Gymnastics Club Gymnastica Portuguez Strauß showed the famous film "Wege zu Kraft und Schönheit" of 1925. After the movie show, he and a group of pupils demonstrated in practice various ways and techniques of the new German concept of Turnen, gymnastics, games, dance and sport.

\section{NAZI-PERIOD, WORLD WAR II, AND PROSPECT}

Things changed fundamentally when Adolf Hitler and the Nazi-Party came to power in 1933 . However, this change announced little by little since the late 1920s, not only in Germany but abroad as well. In Brazil, the German Nazi Party had quite a lot of fans and organized groups supporting NS politics and ideology. Some of them were among the Turners too. So-called Ortsgruppen of the Nazi party in Brazil tried to subordinate the Turner Clubs to the Nazi party. The consequence of this politics was the division of the Turner Clubs. But some Turnvereine refused to do that, not least by the support of J. Aloys Friederichs who succeeded in convincing the Clubs to resist the pressure of the Nazi Party in Porto Alegre. (Hesslein 1949, p. 5f) However, in the eyes of the secret police, the Turnvereine got a reputation as the "fifth gang of the Nazi Party" (Silva Py, 1942).

Prologue, outbreak, duration, process, and, finally, the disastrous end of World War II had strong consequences for the Germans abroad including Brazil. The German Turnvereine in Brazil 
were pushed (or forced) to introduce Portuguese their official language. German was not any more the language of the Turnvereine in Brazil. The "campaign of Nationalization" in Brazil, beginning in 1937, accelerated the process of Brasilianization of the Germans. Due to the Nazi politics and their promotion of the War, many German Vereine had to be closed. The police for example sealed the Turner hall of the Turnverein in Brusque. The army occupied the playgrounds of the Teuto-Brazilian Turner Club in Curtiba. Similar things happened in Blumenau where the army had occupied the house of the shooting club. The police burnt the library of the Turnverein in Ponto Grossa, PR. Tomb slabs of the cemetery with German inscriptions in Joinville were destroyed. Elderly German people being unable to speak Portuguese did not dare to leave the house anymore. Mobbing and hostility against Germans were usual. Some Chairmen of German Clubs crushed out their archives implying that the "social memory" of these clubs got lost. Some closed their doors forever.

However, not all German Clubs were persecuted. The actions against them also depended from local situations. In Porto Alegre, the Turner Society succeeded in overcoming the crisis quite well thanks to their networking with the government and state institutions. His name was now Sociedade de Ginástica Porto Alegre. The Club participated regularly at the "semanas da patria" and showed performances in gymnastics at the celebrations of the 200st anniversary of the city in 1941. In 1942, the Club even succeded in celebrating its $75^{\text {th }}$ anniversary including major public performances.

\section{POST-WAR PROSPECTS}

Clube Duque de Caxias, Esporte Clube Rio Branco, Clube de Regatas Guaíba, Clube União, Clube 15 de Novembro, Tabajara Tênis Clube, who could imagine that these Clubs had been founded by German immigrants?! Renamed in Portuguese, some of these Clubs experienced a restauration after World War II since the 1950s. Sporting life came up again, and some of them even organized cultural activities like singing and conversation circles, sometimes even in German again. However, German culture became a kind folkloristic memory. Jahns busts were banned to the lofts. The dying old Germans took their ideology of Germanism to their tomb.

In 1952, the former team of the Olympiariege 1936, respectively those who had survived War and Nazism, toured through Southamerika, 
Brazil, Argentina, and Chile. Hans Reip organized this voyage of the "diplomats in white", as he named them in his documentary book. "The War has cut many old connections", he commentated. The tour became a great success. Walter Kolb, haunted by the Nazi regime and first Chairman of the German Turner Association, regarded the tour as a proof for his thesis of the "power of the idea of Turnen and the Olympic idea for friendship among peoples".

Actually, former German Turner Clubs could increase during the decades after the early 1950s. They became many members and some of them became wealthy professional sports clubs too. They still are an element of local life and culture especially for sports and gymnastics like Handebol and Punhobol being respected as "German imports". Some of these Clubs are still aware of their German heritage.

\section{CONCLUSIONS}

This perception of role of German gymnastics clubs based on original documents prove the thesis of the French historian Jean Roche that the initiating process of sports in Brazil was by no means only influenced by English or British. "Many contents and forms of physical fitness and exercises or of natural ways of living (...) was initiated by German immigrants" maintains Roche (Roche 1959, p. 594 f.). "Even most parts of sports like cycling (1889), football (1903), rowing (1888), tennis (1898) or even motor races (1927) by cars were initiated by Germans and their descenders, or at least by persons who had reached an established range in Brazilian society." (Oberacker 1971, p. 32).

The German-Brazilian historian Oberacker adds the list of Roche with sports like yachting and sailing, fencing, climbing, and gliding flight deriving mostly from initiatives of immigrated Germans. The Turner Clubs and the shooting clubs were mainly responsible for the prevalence of organized swimming, athletics, handball, and of course gymnastics in Brazil. However, resumes Oberacker, the flourishing club live had been destroyed on the eve of World War II (Oberacker 1971, p. 32).

In fact and in sum, the historical documents like the "Jahrhundertbuch" of the Swiss priest Theodor Amstad for Rio Grande do Sul of 1924 and many articles in the "atlantes" (Atlanten) of Brasilian sport history clearly show that Germans had strongly influenced the development of gymnastics, physical education, games and sports at least in their immigration areas. This result may be especially true for the period after 1870 until the late 1930s (See timeline). 


\section{BIBLIOGRAPHY (CITED LITERATURE AND DOCUMENTS)}

Anuário do Staden (1988). Estudos Brasileiros. São Paulo: Fundação Martius, No. 36.

Atlas do esporte no Brasil (2005). Atlas do esporte, educação física e atividades físicas de saúde e lazer no Brasil. Lamartine da Costa (org.). Rio de Janeiro: Shape.

Atlas do esporte no Rio Grande do Sul (2005). Janice Zarpellon Mazo e Alberto Reinaldo Reppold Fo. (org.). Porto Alegre.

Delhaes-Guenther, D. (1973). Industrialisierung in Südbrasilien. Die Deutsche Einwanderung und die Anfänge der Industrialisierung in Rio Grande do Sul. Köln and Wien: Böhlau.

Euler, C. (Ed. Hrsg.) (1885). Friedrich Ludwig Jahns Werke. Hof: Lion.

Fest-Schrift zum Ed. 50-jährigen Jubiläum des Deutschen Turnvereins zu Joinville am 14., 15. und 16. November (1908). Joinville: Selbstverlag.

Fest-Schrift zum 5. Deutschen Turn-Fest in Porto Alegre am 19., 20. und 21. Oktober 1907 (1907). Porto Alegre: Cäsar Reinhardt.

Friederichs, J. A. (1922). Liederbuch. Porto Alegre: Typographia Mercantil.

Friederichs, J. A. (1928). Reden bei Feiern der Turnerschaft und des Verbandes Deutscher Vereine. São Leopoldo: Rotermund \& Co.

Hesslein, Pablo (1949). Politische Briefe. Santiago de Chile. VI, Nr. 71.

Koseritz' Deutscher Volkskalender für die Provinz Rio Grande do Sul (1874). Porto Alegre 1.

Mazo, Janice Zarpellon; Lyra, Vanessa Bellani (2010). Nos rastros da memória de um “Mestre de Ginástica”. Em: Motriz, Rio Claro, v. 16 n. 4 p. 967-976, out./dez. 2010.

Oberacker, K. H. (1971). Die Einführung des Fußballspiels und anderer Sportarten in Brasilien. In: Zeitschrift für Kulturaustausch, 21. Jg. (1971), H. 3, S. 31-32.

Oliveira, Paulo Gilberto (1987). A imigração alemã e a introdução do punhobol no Rio Grande do Sul. Dissertação (Maestrado em Ciência do Movimento Humano) UFSM, 1987.

Quitzau, E. A. (2011). Educação do corpo e vida associativa: as sociedades ginásticas alemãs em São Paulo (fins do século XIX, primeiras décadas do século XX). [dissertação]. Campinas (SP): Universidade Estadual de Campinas.

Quitzau, E. A. (2012). “O Trabalho na Forma de Alegria Juvenil”: A Ginástica segundo Johann Christoph Friedrich Guts Muths. In: Rev. Bras. Ciênc. Esporte, Florianópolis, v. 34, n. 2, abr./jun., pp. 359-373.

Quitzau, E. A. (2015). Da "Ginástica para a juventude" a "A ginástica alemã": observações acerca dos primeiros manuais alemães de ginástica. In: Revista Brasileira de Ciência do Esporte, v. 37, n. 2, p. 111-118.

Quitzau, E. A. (2016). Associativismo ginástico e imigração alemã no Sul e Sudeste do Brasil (1858-1938). Diss. Universidade Estadual de Campinas. 
Tesche, L. (1996). A Prática do Turnen entre os Imigrantes Alemães e seus Descendentes no Rio Grande do Sul: 1867-1942. Ijuí: Editora Unijuí (Série Dissertações de Mestrado).

Tesche, L. (2002). O Turnen, a Educação e a Educação Física nas escolas teutobrasileiras no Rio Grande do Sul: 1852-1940. Ijuí: Editora Unijuí.

Turnerschaft von Rio Grande do Sul (Ed.) (1929). Festschrift zum VII. Turnfest der Turnerschaft von Rio Grande do Sul vom 17., 18., 19. u. 20. Mai 1929 in Porto Alegre. Porto Alegre: Typographia do Centro.

\section{ADDITIONAL LITERATURE AND DOCUMENTS}

Allgemeine Auswanderungszeitung, 19 (1864) Nr. 14, 31. 3.

Bercht, A., \& Englert, G., \& Friederichs, J. A (1937). Grundsätzliche Betrachtungen zur Anschlussfrage. Selbstverlag.

Cem Anos de germanidade no Rio Grande do Sul, São Leopoldo: Ed. Unisinos, 2000. [= Hundert Jahre Deutschtum, 1924, s. Verband Deutscher Vereine]

Chronik des Verbandes Deutscher Vereine Porto Alegre (1886-1936) (1936). Porto Alegre: Typographia Mercantil.

Fausel, E. (s. d). Alberto Bins: O Merlense Brasileiro. São Leopoldo: Rotermund \& Cia.

Fischer, M. (1929). Festschrift zum VII. Turnfest der Turnerschaft von Rio Grande do Sul. Porto Alegre: Typographia do Centro.

Friederichs, J. A. (1929). Die Bismarckrunde in Porto Alegre. Ihre Entstehung und Entwicklung. Porto Alegre: Typographia Mercantil.

Hinden, H. (1921). Deutsche und deutscher Handel in Rio de Janeiro 1821-1921. Rio de Janeiro: Hoepfner.

Hofmeister Fo, C. (1987). Doze Décadas de História. Porto Alegre: Sogipa.

Hoppe Kipper, M. (1979). A Campanha de Nacionalização do Estado novo em Santa Cruz (1937-1945). Santa Cruz do Sul.

Hundert Jahre Deutschtum, s. Verband Deutscher Vereine (1924).

Jahn, F. L. (1928). Das Deutsche Volksthum. Nach der Originalausgabe von 1810. Dresden. (Quellenbücher der Leibesübungen, Bd. 3.)

Kleber da Silva, H. R. (2005). A Trejetória de uma Liderança Étnica. J Aloys Friederichs (1868-1950). Diss. Porto Alegre, UFRGS.

Lemos, J. S. (2015). Brummers. A Legião Alemã Contrada pelo Império Brasileiro em 1851. Porto Alegre: EDIGAL.

Lopes, A. (2003). Albert Richard Dietze. Um Artista-Fotógrafo Alemão no Brasil do Século XIX. Vitória: Editora A1. 
Mauch, C., \& Vasconcellos, N. (Orgs.) (1994). Os Alemães no Sul do Brasil: Cultura, Etnicidade, História. Canoas: Ed. ULBRA.

Messele-Wieser, S., \& Wieser, L. (1993). Neues Heimatland Brasilien. Texte und Bilder zur kulturellen Entwicklung der deutschbrasilianischen Bevölkerung in Südbrasilien. Göttingen: SUB.

Messele-Wieser, S. (2013). „Brasilien“. „Brasil“. Ferdinand Schlatter. Der Lindauer Maler in Rio Grande do Sul. O Pintor de Lindau no Rio Grande do Sul. Baunach: Spurbuchverlag.

Nipperdey, T. (1976). Verein als soziale Struktur in Deutschland im späten 18. und frühen 19. Jahrhundert. Eine Fallstudie zur Modernisierung I. In: Ders.: Gesellschaft, Kultur, Theorie. Gesammelte Aufsätze zur neueren Geschichte. Göttingen.

Petry, S. M. V. (1982). Os Clubes da Caça e Tiro na Região de Blumenau - 1859-1981. Blumenau: Fundação "Casa Dr. Blumenau”.

Programa oficial da "Primeira Pequena Olimpíada" (1945). Competição esportiva entre os representantes oficiais da Republica Oriental do Uruguai e da Sociedade de Ginástica Pôrto Alegre, 1867. De 18 á 23 de Julho de 1945. Porto Alegre: Livraria Continente.

Reip, H. (1953). Diplomaten in Weiß. Die Südamerikareise der deutschen Olympiaturner. Herausgegeben im Auftrage der Deutschen Turn- und Sportvereine Südamerikas. Frankfurt: Olympischer Sport-Verlag.

Roche, J. (1969). A Colonização Alemã e o Rio Grande do Sul. Porto Alegre: Livraria do Globo. [frz. Originalausgabe, Paris 1959]

Rühl, H. (1901). Deutsche Turner in Wort und Bild. Leipzig; Wien: Pichlers Wittwe.

Schulze, F. (2016). Auswanderung als nationalistisches Projekt: „Deutschtum“ und Kolonialdiskurse im südlichen Brasilien (1824-1941). Köln; Weimar; Wien: Böhlau Verlag.

Seyferth, G. (1981). Nacionalismo e Identidade Étnica. Florianópolis: Fundação Catarinense de Cultura.

Silva, H. (1997). SOGIPA: Uma Trajetória de 130 Anos. Porto Alegre: Sogipa.

Silva, H. (2001). Oktoberfest 90 Anos. Porto Alegre: Sogipa.

Silva Py, A. (1942). A 5a. Coluna no Brasil. A Conspiracão Nazi no Rio Grande do Sul. Porto Alegre.

SOGIPA (1967). $1^{\circ}$ Centenário”. Porto Alegre: Sogipa.

SOGIPA (1942). Álbum Comemorativo ao $75^{\circ}$ Aniversário da Sociedade de Ginástica Porto Alegre - 1867. Porto Alegre: Sogipa.

Spalding, W. (1969). Construtores do Rio Grande. Porto Alegre: Livraria Sulina Editora.

Telles, L. (1974). Do Hilfsverein ao Colégio Farroupilha. Porto Alegre: Associação Beneficente e Educaional de 1858. 
Telles, L. (1974). A Bismarckrunde em Porto Alegre. Anais do $1^{\circ}$ Simpósio de História da Imigração e Colonização Alemã no Rio Grande do Sul. S. 191-219.

Turner-Bund Porto Alegre (1892-1917). Porto Alegre: Typographia Mercantil, 1917.

Verband Deutscher Vereine (Ed. Hrsg.) (1924). Hundert Jahre Deutschtum in Rio Grande do Sul. Porto Alegre: Typographia do Centro.

Wettstein, K. A (о. J.). Mit deutschen Kolonistenjungen durch den brasilianischen Urwald. Leipzig: Engelmann.

Wieser, L. (1990). Deutsches Turnen in Brasilien. London: Arena.

Wieser, L. (1995). Os primórdios das Sociedades Ginásticas Brasileiras até a unificação em associações. Boletim do Arquivo Histórico de Joinville, Joinville, Nr. 13, S. 7-37.

Wieser, L. (2013). „Gut Pfad“ und „Allzeit bereit“. Deutsche Pfadfinder in Brasilien. In: Scouting Jahrbuch 2013. Baunach: Spurbuchverlag, S. 158-163.

Wieser, L. (2014). „Das hiesige Land gleich einem Paradies“. Die Auswanderung von Baden nach Brasilien im 19. Jahrhundert. Ubstadt-Weiher: verlag regionalkultur.

Wieser, L. (2016). Der „Götz-Stein“ in Porto Alegre - Ein Turnerdenkmal in Südbrasilien. In: Jahn-Report. 43. Ausgabe, Dez., S. 32-36.

Wieser, L. (2017). Ein Turnplatz im Urwald von Espírito Santo, Brasilien. In: Jahn-Report, 45. Ausgabe, Dez., S. 16-19.

Willems, E. (1980). A aculturação dos alemães no Brasil. Estudo antropológico dos imigrantes alemães e seus descendentes no Brasil. Brasília: Cia. Ed. Nacional.

\section{WEBSITES OF FORMER GERMAN CLUBS (VEREINE) (SELECTION)}

http://clubeginastico.com/br/ (= Turnverein Joinville, SC)

http://cluberiobranco.com.br/institucional/ (= Handwerker-Unterstützungsverein Curitiba, PR)

http://www.clubeduquedecaxias.com.br/pagina/t1/o-clube/7_historia.html (= TeutoBrasilianischer Turnverein Curitiba, PR)

http://www.ecp.org.br/wp-content/uploads/2018/03/atividades_promemoria.jpg (= Esporte Clube Pinheiros, São Paulo)

http://sgnh.com.br/sgnh/a-historia/ (= Turnverein Neu Hamburg Sociedade de Ginástica Novo Hamburgo, RS)

https://www.sogipa.com.br/web/ (= Turnerbund Porto Alegre Sociedade de Ginástica Porto Alegre, RS)

https://gremio.net/conteudo/index/44 (= Grêmio Football Porto Alegrense, RS) 
https://www.scriogrande.com/ (= Sport Club Rio Grande, RS)

http://www.cgdrj.com.br/clube_historico.html (= Turnverein Rio de Janeiro)

http://www.gpa1888.com.br/ (= Ruder-Club Porto Alegre, RS)

http://soges.com.br/a-historia-da-soges/ (= Turnverein Estrela, RS)

http://www.sociedadeginastica.com.br/ (= Turnverein Sao Bento do Sul, SC)

http://www.sogiijui.com.br/paginas/historico (= Turner- und Sängerbund Ijuí, RS)

http://vds.com.br/ (Clube Veleiros do Sul, Porto Alegre, Segelsport, Co-founder: Ewald Ritter)

http://jangadeiros.com.br/2017/12/como-nasceu-o-jangadeiros/ (Segelverein, Porto Alegre, Founder: Leopold Geyer)

http://iateclubeguaiba.com.br/o-clube/ (Segelsport, Yacht Club Guaíba, Porto Alegre. Founder: Leopold Geyer) 
TIMELINE OF THE HISTORY OF GYMNASTICS, SPORTS, AND GAMES IN BRAZIL AND GERMANY ${ }^{3}$

\begin{tabular}{|l|l|}
\hline \multicolumn{2}{|c|}{ Gymnastics and Sports until 1929 } \\
\hline Germany & Brazil \\
\hline $\begin{array}{l}1811 \\
\text { Friedrich Ludwig Jahn (1778-1852), } \\
\text { the Turnvater (father of gymnastics), } \\
\text { establishes the "Hasenheide", the first } \\
\text { gymnastic ground, in Berlin. }\end{array}$ & $\begin{array}{l}1818 \\
\text { Start of German immigration (RJ) }\end{array}$ \\
\hline $\begin{array}{l}1816-1820 \\
\text { Founding of the first Gymnastics } \\
\text { grounds and Clubs throughout Germany }\end{array}$ & $\begin{array}{l}1822 \\
\text { Carl Freiherr von Dreis, originally } \\
\text { travelling to Brazil as a land surveyor } \\
\text { in behalf of Baron von Langsdorff, } \\
\text { presents his "Laufmaschine" (dandy } \\
\text { horse) to the emperor in Rio de Janeiro }\end{array}$ \\
\hline $\begin{array}{l}1820 \\
\text { "Turnsperre" (prohibition of gymnastic } \\
\text { clubs in Prussia) }\end{array}$ & $\begin{array}{l}1824 \\
\text { Foundation of São Leopoldo, RS }\end{array}$ \\
\hline $\begin{array}{l}\text { Adolf Spieß develops a complex } \\
\text { gymnastics system in the tradition of } \\
\text { Jahn }\end{array}$ & $\begin{array}{l}1829 \\
\text { Foundation of São Pedro de Alcantara } \\
\text { (SC) and Rio Negro (PR) }\end{array}$ \\
\hline $\begin{array}{l}\text { Lifting of prohibition, founding of } \\
\text { gymnastic clubs continues }\end{array}$ & $\begin{array}{l}1830 \text { er } \\
\text { Julius (Júlio) Frank initiates a student's } \\
\text { corporation in São Paulo, inspired by } \\
\text { the German idol }\end{array}$ \\
\hline $\begin{array}{l}1840 \text {-1846 of the first period of German } \\
\text { immigration }\end{array}$ \\
\hline & \\
\hline 1842 &
\end{tabular}




\begin{tabular}{|l|l|}
\hline $\begin{array}{l}1846 \\
\text { (German) Turnfest in Heilbronn. } \\
\begin{array}{l}\text { Foundation of numerous Turner Clubs } \\
\text { (Turnvereine), mainly in the South of } \\
\text { Germany }\end{array}\end{array}$ \\
\hline $\begin{array}{l}1847 \\
\text { In the "Turnbuch für Schulen" (School } \\
\text { exercise book for the direction of } \\
\text { exercise instruction by teachers) } \\
\text { Spieß introduces methods for teaching } \\
\text { physical education in schools }\end{array}$ & \\
\hline $\begin{array}{l}1848 \\
\text { Foundation of the German and the } \\
\text { Democratic Gymnastics Federation } \\
\text { (Turnerbund) }\end{array}$ & \\
\hline $\begin{array}{l}1848 / 49 \\
\text { The German revolutions of 1848-49 }\end{array}$ & \\
\hline $\begin{array}{l}1849-1860 \\
\text { Oppression of the civilian German } \\
\text { opposition including the gymnasts } \\
\text { (Turners) }\end{array}$ & $\begin{array}{l}\text { Sebastião do Rego Barros recruits } \\
\text { soldiers for Brazil - numerous of them } \\
\text { remain in Brazil }\end{array}$ \\
\hline & $\begin{array}{l}1858 \\
\text { Foundation of the first German Turner } \\
\text { Club (Deutscher Turnverein) in Brazil in } \\
\text { Joinville }\end{array}$ \\
\hline & $\begin{array}{l}1859 \\
\text { Foundation of German Turner Clubs in } \\
\text { Rio de Janeiro }\end{array}$ \\
\hline & $\begin{array}{l}1862 \\
\text { Seven Turners climb on the sugarloaf in } \\
\text { Rio hoisting a German flag in black-red- } \\
\text { gold. } \\
\text { A stone of the sugarloaf is sent to } \\
\text { Berlin and was fixed in the Jahn } \\
\text { monument in Berlin }\end{array}$ \\
\hline
\end{tabular}




\begin{tabular}{|c|c|}
\hline $\begin{array}{l}1859 \\
\text { Franco-Austrian War (Second Italian } \\
\text { War of Independence) } \\
\text { In the aftermath of the war, the } \\
\text { German nationalist movement is } \\
\text { steadily growing. } \\
\text { After a decennial period of } \\
\text { restauration, ceremonies in honor of } \\
\text { Friedrich Schiller, the so called "poet } \\
\text { of liberty", remind of the revolutionary } \\
\text { aspirations in the years } 1848 / 49 \text {. In } \\
\text { the ensuing months numerous Turner } \\
\text { Clubs are revived. }\end{array}$ & $\begin{array}{l}1864 \\
\text { Gymnastics and sport shooting: } \\
\text { Karl von Koseritz reports to } \\
\text { the newspaper "Allgemeine } \\
\text { Auswanderungs-Zeitung" (specialized } \\
\text { on emigration) of Gotha the existence } \\
\text { of gymnastics clubs and shooting/rifle } \\
\text { clubs in Rio Grande do Sul }\end{array}$ \\
\hline $\begin{array}{l}1860 \\
\text { June 17/18 German Turnfest in Coburg }\end{array}$ & \\
\hline $\begin{array}{l}1861 \\
\text { August 10/12 German Turnfest in Berlin }\end{array}$ & \\
\hline $\begin{array}{l}1863 \\
\text { August 2/5 German Turnfest in Leipzig }\end{array}$ & \\
\hline $\begin{array}{l}1866 \\
\text { Austro-Prussian War (German War) } \\
\text { was fought between the Austrian } \\
\text { Empire and the Kingdom of Prussia }\end{array}$ & $\begin{array}{l}1866 \\
\text { Skittles: } \\
\text { First skittle club in Santa Cruz do Sul, } \\
\text { RS }\end{array}$ \\
\hline $\begin{array}{l}1868 \\
\text { Juli } 21 \text { German Turnfest in Weimar } \\
\text { Foundation of the German Gymnastics } \\
\text { Federation (Deutsche Turnerschaft) }\end{array}$ & $\begin{array}{l}1869 \\
\text { Sport shooting } \\
\text { Porto Alegre, 9th Januar 1869: } \\
\text { renaming of the German Turners Club } \\
\text { (Deutscher Turnverein) in German } \\
\text { Turners and Shooting Club (Deutscher } \\
\text { Turner- und Schützenverein). Secretary: } \\
\text { Karl von Koseritz Blumenau, SC, } \\
\text { Schützenverein, founded } 2 \text { December, } \\
\text { birthday of the emperor Dom Pedro II } \\
\text { Foundation of Shooting Clubs in the } \\
\text { valley of Itajaí. Foundation of numerous } \\
\text { Shooting Clubs in and around Santa } \\
\text { Cruz, RS }\end{array}$ \\
\hline
\end{tabular}




\begin{tabular}{|c|c|}
\hline $\begin{array}{l}1871 \\
\text { Franco-Prussian War } \\
\text { Proclamation of the German Empire }\end{array}$ & $\begin{array}{l}1871 \\
\text { Establishment of Physical Education } \\
\text { (Schulturnen) in Joinville initiated by } \\
\text { the local Turners Club }\end{array}$ \\
\hline & $\begin{array}{l}1876 \\
\text { Foundation of the German Turnverein } \\
\text { Colonia Santa Leopoldina (ES) by Albert } \\
\text { Richard Dietze. }\end{array}$ \\
\hline \multirow[t]{2}{*}{$\begin{array}{l}1876 \\
\text { Introduction of Lawn Tennis in } \\
\text { Germany }\end{array}$} & $\begin{array}{l}1876 \\
\text { Foundation of German Turner Clubs in } \\
\text { São Paulo }\end{array}$ \\
\hline & $\begin{array}{l}1880 \\
\text { German Turner Clubs in São Leopoldo, } \\
\text { officially founded in } 1885\end{array}$ \\
\hline $\begin{array}{l}1881 \\
\text { Programmatic paper of E. Hartwich } \\
\text { "Woran wir leiden“ (What we suffer } \\
\text { from) on the needs for a healthy } \\
\text { lifestyle and movement }\end{array}$ & $\begin{array}{l}1881 \\
\text { Long distance swimming: The German } \\
\text { immigrant and clockmaker Theodor } \\
\text { John swims through the bay of } \\
\text { Guanabara in Rio de Janeiro }\end{array}$ \\
\hline \multicolumn{2}{|l|}{$\begin{array}{l}1882 \\
\text { Introduction of play and games at } \\
\text { schools (Spielerlass by the Prussian } \\
\text { secretary von Goßler) }\end{array}$} \\
\hline $\begin{array}{l}1882 \\
\text { First German race course for cycling in } \\
\text { Munich }\end{array}$ & \\
\hline \multirow[t]{2}{*}{$\begin{array}{l}1883 \\
\text { Foundation of the German Rowing } \\
\text { Association }\end{array}$} & \\
\hline & $\begin{array}{l}1884 \\
\text { The Craftmen Support Association } \\
\text { (Handwerker-Unterstützungsverein) } \\
\text { was founded in Curitiba, including a } \\
\text { gymnastics section }\end{array}$ \\
\hline
\end{tabular}




\begin{tabular}{|l|l|}
\hline & $\begin{array}{l}1885 \\
\text { Swimming: German Turners Club Porto } \\
\text { Alegre. First swimming bath of Brazil } \\
\text { established in Rio Guaiba. swimming } \\
\text { festivals (Schwimmfeste) for the } \\
\text { financing of the swimming bath. }\end{array}$ \\
\hline & $\begin{array}{l}1885 \\
\text { Sport Shooting: 8th September in } \\
\text { Porto Alegre, founding of the Shooting } \\
\text { Association (Schützenbund) for Rio } \\
\text { Grande do Sul }\end{array}$ \\
\hline Foundation of the German Cycling & $\begin{array}{l}1885 \\
\text { Fencing: German Turners Club Porto } \\
\text { Alegre resolves to include fencing into } \\
\text { the exercise programme }\end{array}$ \\
\hline Association & $\begin{array}{l}1886 \\
\text { Sport Shooting: April, First Federal } \\
\text { Sport Shooting Event (Erstes } \\
\text { Bundesschießen) in São Leopoldo } \\
\text { attended by prince Gaston of Orleans, } \\
\text { Conde d'Eu, who donates a target rifle } \\
\text { (Scheibengewehr) }\end{array}$ \\
\hline & $\begin{array}{l}1887 \\
\text { March 6, foundation of the German } \\
\text { Turners Club São João do Montenegro }\end{array}$ \\
\hline & $\begin{array}{l}1888 \\
\text { Rowing: Rowing Club Porto Alegre, } \\
\text { founded with the participation of } \\
\text { Alfred Schütt, Balduin Röhrig and } \\
\text { Alberto Bins, who will henceforth } \\
\text { become Lord Mayor of Porto Alegre. } \\
\text { The Club imports two gigs with four } \\
\text { and six paddles from Germany. }\end{array}$ \\
\hline & $\begin{array}{l}\text { 1888 } \\
\text { December 2. Foundation of the German } \\
\text { Turners Club São Paulo }\end{array}$ \\
\hline & \\
\hline &
\end{tabular}




\begin{tabular}{|c|c|}
\hline $\begin{array}{l}1890 \\
\text { Paddling and Canoeing }\end{array}$ & $\begin{array}{l}1890 \\
\text { Foundation of Turners Club Lomba } \\
\text { Grande }\end{array}$ \\
\hline & $\begin{array}{l}1890 \\
\text { Foundation of Turnerschaft (a single } \\
\text { Club) São Paulo }\end{array}$ \\
\hline $\begin{array}{l}1891 \\
\text { May 21: Foundation of the Central } \\
\text { Committee for National and Youth } \\
\text { games (Zentralausschusses für Volks- } \\
\text { und Jugendspiele) in Berlin }\end{array}$ & \\
\hline \multirow[t]{2}{*}{$\begin{array}{l}1893 \\
\text { July 15: Foundation of the German } \\
\text { Worker's Society (Arbeiter- Turn- und } \\
\text { Sportbund; ATB) in Gera }\end{array}$} & $\begin{array}{l}1893 \\
\text { September 15: German Turners Club } \\
\text { Santa Cruz is founded. }\end{array}$ \\
\hline & $\begin{array}{l}1894 \\
\text { July 11: Turners Club Neu Hamburg is } \\
\text { founded }\end{array}$ \\
\hline \multirow[t]{2}{*}{$\begin{array}{l}1894 \\
\text { June 16: Pierre de Coubertin calls for } \\
\text { an International Sports Congress in } \\
\text { Paris. Foundation of the International } \\
\text { Olympic Committee (Comité } \\
\text { Internationale Olympique) (CIO) }\end{array}$} & $\begin{array}{l}1894 \\
\text { Health: 1st Natural Healing Association } \\
\text { in Rio Grande do Sul, founded 4th } \\
\text { March. Registered under number } 435 \\
\text { in the German Federation of Natural } \\
\text { Healing Associations (Deutscher Bund } \\
\text { der Naturheilvereine), headquartered } \\
\text { in Berlin. Primary objective, goals: } \\
\text { increase awareness of a healthy } \\
\text { lifestyle, supplemented by propagating } \\
\text { free exercise during in daylight, air and } \\
\text { water }\end{array}$ \\
\hline & $\begin{array}{l}1895 \\
\text { Gymnastics: Founding of the German } \\
\text { Turners Association (Deutsche } \\
\text { Turnerschaft) of Rio Grande do Sul. }\end{array}$ \\
\hline
\end{tabular}




\begin{tabular}{|c|c|}
\hline & $\begin{array}{l}1896 \\
\text { Soccer: belongs to the Turners games } \\
\text { (Turnspiele), in Porto Alegre }\end{array}$ \\
\hline & $\begin{array}{l}1896 \\
\text { Cycling: The Cycling Club "Blitz" } \\
\text { is founded. Founding member: } \\
\text { Alberto Bins, Oskar Schaitza, who is } \\
\text { administrator of the swimming bath of } \\
\text { the Turners Federation, is elected } 1 . \\
\text { Chairman. }\end{array}$ \\
\hline & $\begin{array}{l}1897 \\
\text { Long distance swimming in Guaíba, } \\
\text { organized by the Rowing Club Porto } \\
\text { Alegre, German Turners Federation } \\
\text { (Deutscher Turnerbund) and the Cycling } \\
\text { Club "Blitz" (March 12, 1897). }\end{array}$ \\
\hline & $\begin{array}{l}1897 \\
\text { Cycling: First cycle race in the City of } \\
\text { Porto Alegre }\end{array}$ \\
\hline & $\begin{array}{l}1897 \\
\text { (Re) Establishment of fencing in the } \\
\text { Turners Club Porto Alegre. Initiator } \\
\text { and long-standing fencing instructor } \\
\text { (Fechtwart): Ferdinand Fenchel. } \\
\text { January 7: Foundation of a fencing } \\
\text { group (Fechtriege) in the Turnerschaft } \\
\text { von São Paulo. Professor: Mr. Reichart }\end{array}$ \\
\hline $\begin{array}{l}1898 \\
\text { January 31: Foundation of the } \\
\text { Athletics Association (Deutschen } \\
\text { Sportbehörde für Athletik) }\end{array}$ & $\begin{array}{l}1898 \\
\text { Tennis: October 22: foundation of the } \\
\text { Tennis Club Walhalla }\end{array}$ \\
\hline $\begin{array}{l}1898 \\
\text { Representatives of the Teuto-Brazilian } \\
\text { Turners Club Curitiba and Turnerschaft } \\
\text { of São Paulo (1890) participate in the } \\
\text { German Turnfest in Hamburg. }\end{array}$ & \\
\hline
\end{tabular}




\begin{tabular}{|c|c|}
\hline & $\begin{array}{l}1899 \\
\text { Sport Shooting: Big shooting event } \\
\text { (Schützenfest) in Porto Alegre }\end{array}$ \\
\hline & $\begin{array}{l}1899 \\
\text { Soccer: Foundation of the sports } \\
\text { club Germania in São Paulo, August } \\
\text { 19. Hamburg born Hans Nobiling is } \\
\text { initiator. }\end{array}$ \\
\hline \multirow[t]{2}{*}{$\begin{array}{l}1900 \\
\text { January 28: Foundation of the German } \\
\text { Football Association (Deutscher } \\
\text { Fußballbund) }\end{array}$} & $\begin{array}{l}1900 \\
\text { Soccer: The Sports Club Rio Grande, } \\
\text { being the oldest continuously existing } \\
\text { "pure" Soccer Club of Brazil, is founded } \\
\text { under German participation }\end{array}$ \\
\hline & $\begin{array}{l}1900 \\
\text { The Turners of São Paulo declare } \\
\text { Dr. Ferdinand Götz, Chairman of the } \\
\text { German Turnerschaft, a honorary } \\
\text { member on the occasion of their 10th } \\
\text { anniversary }\end{array}$ \\
\hline $\begin{array}{l}1902 \\
\text { May 19: Foundation of the German } \\
\text { Lawn-Tennis Association in Berlin }\end{array}$ & $\begin{array}{l}1902 \\
\text { Women Turners: The Turners } \\
\text { Federation founded in } 1890 \text { in São } \\
\text { Paulo establishes a women league, } \\
\text { which is model to the Turners of Porto } \\
\text { Alegre. }\end{array}$ \\
\hline \multirow[t]{2}{*}{$\begin{array}{l}1903 \\
\text { Representatives of the Turners } \\
\text { Federation Porto Alegre participate in } \\
\text { the German Turnfest in Nuremberg. }\end{array}$} & $\begin{array}{l}1903 \\
\text { Soccer: Following the demonstration } \\
\text { game by the soccer team from Rio } \\
\text { Grande, two soccer clubs are founded } \\
\text { in Porto Alegre: Grêmio Football } \\
\text { Porto-Alegrense and Fußball Club Porto } \\
\text { Alegre. }\end{array}$ \\
\hline & $\begin{array}{l}1903 \\
\text { Gymnastic teacher Georg Black plays } \\
\text { in the team of Grêmio Football Porto- } \\
\text { Alegrense }\end{array}$ \\
\hline
\end{tabular}




\begin{tabular}{|c|c|}
\hline $\begin{array}{l}1908 \\
\text { First relay Potsdam-Berlin }\end{array}$ & $\begin{array}{l}1908 \\
\text { Soccer: The soccer team "Frisch Auf!" } \\
\text { of the Turnerbund Porto Alegre is } \\
\text { founded, initiated by gymnastic teacher } \\
\text { Georg Black. Becomes strongest } \\
\text { subdivision of the club in } 1915 .\end{array}$ \\
\hline $\begin{array}{l}1908 \\
\text { Delegation of Brazil visit the German } \\
\text { Turnfest in Frankfurt }\end{array}$ & \\
\hline $\begin{array}{l}1910 \\
\text { Foundation of the first Youth hostels }\end{array}$ & $\begin{array}{l}1909 \\
\text { Gymnastics: October 16: a new } \\
\text { German Turners club is founded in Rio } \\
\text { de Janeiro. }\end{array}$ \\
\hline \multirow[t]{2}{*}{$\begin{array}{l}1911 \\
\text { January 9: Foundation of the German } \\
\text { Boy Scout Union } \\
\text { Nov 13: Foundation of the } \\
\text { Jungdeutschlandbund (a militaristic } \\
\text { Youth organization) }\end{array}$} & $\begin{array}{l}1911 \\
\text { Fistball: Gymnastic teacher Georg } \\
\text { Black starts fistball within the } \\
\text { framework of the club. }\end{array}$ \\
\hline & $\begin{array}{l}1911 \\
\text { Oktoberfest: The Bavarian folklore } \\
\text { group of the "Haberer" celebrates the } \\
\text { first Oktoberfest on the grounds of the } \\
\text { Turners Federation in Brazil. Initiator: } \\
\text { Ferdinand Schlatter. }\end{array}$ \\
\hline $\begin{array}{l}1913 \\
\text { Delegation of Brazilian Gymnasts and } \\
\text { sportsmen at the German Turnfest in } \\
\text { Leipzig. } \\
\text { Gymnastics teacher Black comes back } \\
\text { to Brazil keeping in mind the idea of } \\
\text { the foundation of boy scout groups in } \\
\text { Brazil }\end{array}$ & $\begin{array}{l}1913 \\
\text { "Eilbotenlauf" (courier run) from Santa } \\
\text { Cruz do Sul to the Bismarck monument } \\
\text { at the shooting stand (Schützenplatz) } \\
\text { in Porto Alegre. Inspired by the } \\
\text { "Jahrhundertlauf" to the monument of } \\
\text { the Battle of the Nations in Leipzig. }\end{array}$ \\
\hline
\end{tabular}




\begin{tabular}{|c|c|}
\hline $\begin{array}{l}1913 \\
\text { Festival for Games and Sports in } \\
\text { the new German Stadium of Berlin } \\
\text { (Deutsches Stadion) } \\
\text { Georg Black of the Porto Alegre } \\
\text { Turners is honored with the Gold medal } \\
\text { for his „all-around performances" } \\
\text { by the German Sports Organization } \\
\text { (DRA). Today the medal is called the } \\
\text { "Deutsches Sportabzeichen. }\end{array}$ & \\
\hline $\begin{array}{l}1914 \\
\text { Military preparation of the youth in } \\
\text { Prussia }\end{array}$ & $\begin{array}{l}1914 \\
\text { "Eilbotenlauf" (courier run) in appraisal } \\
\text { of the return of the chairman J. A. } \\
\text { Friederichs of the Turners Federation } \\
\text { from Germany. Inspired by the Turners } \\
\text { Club São Sebastião do Caí }\end{array}$ \\
\hline \multirow[t]{4}{*}{$\begin{array}{l}1914-1918 \\
\text { First World War }\end{array}$} & $\begin{array}{l}1914 \\
\text { Tennis: The Tennis Club Germania is } \\
\text { founded within the Turners Federation } \\
\text { in December }\end{array}$ \\
\hline & $\begin{array}{l}1915 \\
\text { Gymnastics: I. German Turnfest, } \\
\text { October 10, in Blumenau. All Turners } \\
\text { Clubs of the Itajaí-District participate. } \\
\text { Foundation of the "Itajahy-Gau" (Union } \\
\text { of Itajahy Turners Clubs). }\end{array}$ \\
\hline & $\begin{array}{l}1915 \\
\text { The Turnerschaft of Rio Grande do Sul } \\
\text { (TRG) cancels the public Turnfest. The } \\
\text { term "deutsch" (German) is discarded } \\
\text { at this point. }\end{array}$ \\
\hline & $\begin{array}{l}1916 \\
\text { International competition in Porto } \\
\text { Alegre: Brazilian athletes versus } \\
\text { Uruguayan athletes. }\end{array}$ \\
\hline
\end{tabular}




\begin{tabular}{|l|l|}
\hline $\begin{array}{l}1917 \\
\text { Foundation of the German National } \\
\text { Committee for Physical Education } \\
\text { (Deutscher Reichsausschuss für } \\
\text { Leibesübungen; DRA) }\end{array}$ & $\begin{array}{l}1917-1919 \\
\text { Due to the war interruption of the } \\
\text { Club activities. Club property is being } \\
\text { destroyed. }\end{array}$ \\
\hline $\begin{array}{l}1920 \\
\text { May 15: Opening of the German } \\
\text { College for Physical Exercise (Deutsche } \\
\text { Hochschule für Leibesübungen) in Berlin }\end{array}$ & $\begin{array}{l}1920 \\
\text { Revival of the sport and associative life } \\
\text { (Vereinswesen). In contrast to the USA } \\
\text { in Brazil German as official language in } \\
\text { the Clubs can be restored }\end{array}$ \\
\hline $\begin{array}{l}1922 \\
\text { German Contest Games in Berlin. }\end{array}$ & 1922 \\
\hline $\begin{array}{l}1923 \\
\text { Delegation of Brazil at the German } \\
\text { Turnfest in Munich }\end{array}$ & \\
\hline
\end{tabular}

\begin{tabular}{|l|l|}
\hline \multicolumn{2}{|c|}{ Sports development between 1924 and 1935} \\
\hline Germany & Brazil \\
\hline & 1924 \\
& TRG "Eilbotenlauf" (courier run), 27th \\
& July. \\
& Biggest sportive demonstration in \\
& Brazil featuring 1200 participants. \\
& Main route: 365 kilometers. \\
\hline & 1924 \\
& 6 th TRG Turnfest including a German \\
& Day (Deutscher Tag), 3 - 6 October, \\
& featuring 270 competitors and 617 \\
& free exercise Turners (Freiübungs- \\
& Turner) \\
\hline
\end{tabular}




\begin{tabular}{|l|l|}
\hline $\begin{array}{l}1925 \\
\text { November 8: Foundation of the German }\end{array}$ & $\begin{array}{l}1925 \\
\text { League Atlética Porto Alegrense } \\
\text { (LAPA), founded February 2, member: } \\
\text { Grêmio Football, Rowing-Club, Clube } \\
\text { Olympics in Frankfurt/M. } \\
\text { de Regatas Guahyba (Ex-Germania), } \\
\text { Turnerbund, Sport Club Eiche }\end{array}$ \\
\hline $\begin{array}{l}1925 \\
\text { Congress on bodily fitness for girls and } \\
\text { women }\end{array}$ & $\begin{array}{l}1925 \\
\text { A fencing division is founded within } \\
\text { the Turnerbund of Porto Alegre under } \\
\text { supervision of Ferdinand Fenchel, } \\
\text { which will later develop into the } \\
\text { fencing league (Fechtriege) “Teutonia" }\end{array}$ \\
\hline $\begin{array}{l}\text { Foundation of the Parliamentary } \\
\text { Committee for body exercises and } \\
\text { physical education }\end{array}$ & $\begin{array}{l}1927 \\
\text { Liga Atlética Rio-grandense (LARG) } \\
\text { linked with LAPA is state-wide } \\
\text { recognised }\end{array}$ \\
\hline $\begin{array}{l}1927 \\
\text { Cycling World Championship in Cologne }\end{array}$ & $\begin{array}{l}1927 \\
\text { Volleyball: The Turnerbund Porto } \\
\text { Alegre implements women volleyball }\end{array}$ \\
\hline $\begin{array}{l}1928 \\
\text { Delegation of Brazil participates at the } \\
14 \text { th German Turnfest in Cologne }\end{array}$ & $\begin{array}{l}1928 \\
\text { The Friedrichs Foundation } \\
\text { (Friedrichsstiftung) supports training of } \\
\text { Vorturners (Turners who demonstrate } \\
\text { an exercise) and promotion of } \\
\text { “Turnwarte” (managers of gymnastics } \\
\text { groups) of the Turnerschaft Rio Grande } \\
\text { do Sul }\end{array}$ \\
\hline $\begin{array}{l}1929 \\
\text { Pentecost: 7th Public Turnfest } \\
\text { (Allgemeines Turnfest) of TRG in the } \\
\text { presence of state president, regional } \\
\text { commander and many personalities of } \\
\text { high rank and importance }\end{array}$ \\
\hline
\end{tabular}




\begin{tabular}{|c|c|}
\hline & $\begin{array}{l}1929 \\
\text { Basketball: The Turners Club of Santa } \\
\text { Cruz do Sul establishes basketball }\end{array}$ \\
\hline & $\begin{array}{l}1929 \\
\text { Foundation of the Federação Rio- } \\
\text { grandense de Tênis in which Tennis } \\
\text { Club Walhalla and Tênis Club Ipiranga } \\
\text { (Ex-Germania) joined }\end{array}$ \\
\hline \multirow[t]{4}{*}{$\begin{array}{l}1930 \\
\text { Max Schmeling becomes World Champ } \\
\text { professional boxing (heavy weight) }\end{array}$} & $\begin{array}{l}1930 \\
20 \text { - } 21 \text { September, "Campeonato de } \\
\text { Esgrima Rio Grandense" of the League } \\
\text { Athletica Rio Grandense takes place. } \\
\text { Numerous victories by the fencing } \\
\text { division of the Turnerbund }\end{array}$ \\
\hline & $\begin{array}{l}1930 \\
\text { Sailing: Foundation of the Yachting } \\
\text { Club Porto Alegre by Leopold Geyer }\end{array}$ \\
\hline & $\begin{array}{l}1931 \\
\text { July: Three Turners Clubs - } \\
\text { Turnerbund Porto Alegre, Turners Club } \\
\text { Navegantes São João Porto Alegre and } \\
\text { Turners Club Santa Cruz do Sul found } \\
\text { the Fencing Association of the Turners } \\
\text { Association of Rio Grande do Sul } \\
\text { (Fechter-Vereinigung der Turnerschaft } \\
\text { von Rio Grande do Sul). } 58 \text { fencers, } \\
\text { leader: Ferdinand Fenchel }\end{array}$ \\
\hline & $\begin{array}{l}1931 \\
\text { Handball: Match between the Turners } \\
\text { of São Paulo and Rio de Janeiro. } \\
\text { Foundation of the Handball Association } \\
\text { in São Paulo (Associação de Handebol) }\end{array}$ \\
\hline
\end{tabular}




\begin{tabular}{|c|c|}
\hline & $\begin{array}{l}1931 \\
\text { Argentinian and Chilean Turners Clubs } \\
\text { inspire a union of all Turners clubs of } \\
\text { South America. }\end{array}$ \\
\hline & $\begin{array}{l}1932 \\
\text { A Statistical survey for the "Deutsche } \\
\text { Turnblätter" of all Turners clubs of } \\
\text { German origin throughout Brazil count } \\
57 \text { Turners clubs in the area between } \\
\text { Rio de Janeiro and Rio Grande do Sul }\end{array}$ \\
\hline & $\begin{array}{l}1932 \\
\text { Motor cycling: Hans Stuck is winner } \\
\text { of the mountain race Rio de Janeiro- } \\
\text { Petrópolis with an Mercedes Car }\end{array}$ \\
\hline & $\begin{array}{l}1932 \\
\text { Swimming: The 17th aged Maria Lenk } \\
\text { (Asssociação Atlética de São Paulo) } \\
\text { is the first woman of South America } \\
\text { participating at Olympic Games in Los } \\
\text { Angeles }\end{array}$ \\
\hline $\begin{array}{l}1933 \\
\text { Brazilian Delagation at the German } \\
\text { Turnfest in Stuttgart }\end{array}$ & $\begin{array}{l}1933 \\
\text { The women group of fencers belonging } \\
\text { to the Turnerbund Porto Alegre, is } \\
\text { founded on 12th April. First women's } \\
\text { competition on 2nd December. }\end{array}$ \\
\hline $\begin{array}{l}1935 \\
\text { Deutscher Reichbund für } \\
\text { Leibesübungen (DRL) (Umbrella } \\
\text { organization for Physical exercises and } \\
\text { Sports in Germany) is founded under } \\
\text { pressure of the Nazi party }\end{array}$ & $\begin{array}{l}1934 \\
\text { TRG establishes "Friesenkampf", } \\
\text { comprising of shooting, epee fencing, } \\
\text { throwing, running and swimming. } \\
\text { Fencing instuctor (Fechtwart) } \\
\text { Fenchel donates a special award } \\
\text { ("Friesenplakette") }\end{array}$ \\
\hline
\end{tabular}




\begin{tabular}{|l|l|}
\hline & $\begin{array}{l}1934 \\
\text { Introduction of "Vorfechterprüfung" } \\
\text { (examination for fencing } \\
\text { demonstrators), awarded with pin and } \\
\text { insignia }\end{array}$ \\
\hline $\begin{array}{l}1934 \\
\text { Sailing: Foundation of the Clube } \\
\text { Veleiros do Sul. 1. Comodore: Ewald } \\
\text { Ritter. }\end{array}$ \\
\hline $\begin{array}{l}1935 \\
\text { 8th Turnfest of TRG on the Memorial } \\
\text { Day of the Guerra dos Farrapos } \\
\text { referred to as "Jahrhundertfeiern der } \\
\text { Farrapen-Revolution" }\end{array}$ \\
\hline
\end{tabular}

\begin{tabular}{|l|l|}
\hline \multicolumn{2}{|c|}{ Sports development between 1935 and 1952} \\
\hline Germany & Brazil \\
\hline & 1935 \\
& $\begin{array}{l}\text { Foundation of a Federation of } \\
\text { German-Brazilian Turners Clubs. } \\
\text { Executive board: Turnerbund Porto } \\
\text { Alegre. Official register: “Deutsche } \\
\text { Turnblätter", Porto Alegre. }\end{array}$ \\
\hline & $\begin{array}{l}1935 \\
\text { Jew Herbert Caro, who fled from Nazi- } \\
\text { Germany, starts to play table tennis in } \\
\text { Porto Alegre. }\end{array}$ \\
\hline & $\begin{array}{l}\text { 1935 } \\
\text { The Turngau “Nord Santa Catharina" is } \\
\text { founded on November 30 in São Bento } \\
\text { de Sul. Including seven clubs of the } \\
\text { area among the Northern part between } \\
\text { Joinville and Canoinhas, counting about } \\
1600 \text { members }\end{array}$ \\
\hline
\end{tabular}




\begin{tabular}{|c|c|}
\hline $\begin{array}{l}1936 \\
\text { Olympic Games in Berlin } \\
\text { A Brazilian team participates } \\
\text { successfully, among others the } \\
\text { swimmer Maria Lenk }\end{array}$ & \\
\hline & $\begin{array}{l}1937 \\
\text { Sailing: International Regatta at } \\
\text { the Guaíba in Porto Alegre between } \\
\text { Uruguay and Argentina }\end{array}$ \\
\hline $\begin{array}{l}1938 \\
\text { Brazilian delegation at the German } \\
\text { Turner and sports festival (Deutsches } \\
\text { Turn- und Sportfest) in Breslau }\end{array}$ & $\begin{array}{l}1938-1942 \\
\text { Nationalization of German clubs, } \\
\text { language prohibitions and repression. }\end{array}$ \\
\hline $\begin{array}{l}1938 \\
\text { German Teams are successful at } \\
\text { Handball World Championships in Berlin }\end{array}$ & \\
\hline $\begin{array}{l}1938 \\
\text { The Nazi party rules the German Sports } \\
\text { movement completely }\end{array}$ & \\
\hline & $\begin{array}{l}1939 \\
\text { Swimming: Maria Lenk finishes first } \\
\text { with world records }\end{array}$ \\
\hline $\begin{array}{l}1940 \\
\text { Various Championships at War }\end{array}$ & \\
\hline $\begin{array}{l}1944 \\
\text { During the War Gymnastics and Sports } \\
\text { are only possible local spaces }\end{array}$ & $\begin{array}{l}1943 \\
\text { The immigrant José Wingen establishes } \\
\text { canoeing in Rio Grande do Sul. }\end{array}$ \\
\hline
\end{tabular}




\begin{tabular}{|c|c|}
\hline $\begin{array}{l}1945 \\
\text { End of the War and capitulation of the } \\
\text { Third Reich } \\
\text { German Sports- and Turners Clubs are } \\
\text { prelimanary forbidden by the Allies }\end{array}$ & $\begin{array}{l}1945 \\
\text { Resumption of club activities under } \\
\text { "nationalized" names, lifting the } \\
\text { prohibition of Portuguese language }\end{array}$ \\
\hline $\begin{array}{l}1945 \\
\text { German Sports Clubs and associations } \\
\text { are re-founded step by step }\end{array}$ & $\begin{array}{l}1945 \\
\text { "Primeira Pequena Olmpíada": } \\
\text { Republica Oriental do Uruguai versus } \\
\text { Sogipa, Porto Alegre }\end{array}$ \\
\hline $\begin{array}{l}1949 \\
\text { Foundation of the Deutscher } \\
\text { Fußballbund (DFB) } \\
\text { Foundation of the National Olympic } \\
\text { Committee for Germany (NOK) }\end{array}$ & \\
\hline \multirow[t]{2}{*}{$\begin{array}{l}1950 \\
\text { Foundation of the German Turners } \\
\text { Federation (Deutscher Turner-Bund; } \\
\text { DTB) } \\
\text { Foundation of the German Sports } \\
\text { Federation (Deutscher Sportbund; DSB) }\end{array}$} & \\
\hline & $\begin{array}{l}1952 \\
\text { The German Olympic Team of Turners, } \\
\text { called as "Diplomats in White", visits } \\
\text { South America }\end{array}$ \\
\hline
\end{tabular}

\section{NOTES}

1 It is difficult to translate adequately the CI of Turners: fresh means powerful and highly motivated; fromm does not mean pius in a religious sense but rather brave; the German word fröblich is not really happy but rather bright, and the word frei means free, independent, and self-conscious, not fixed any more on traditional authorities.

2 Turnverein Rio de Janeiro. Vereinszeitung Jg. 2, (1927), Nr. 17 (July). The title of the special issue was Deutsches Turnen in Südamerika. The edition was a kind of advertising brochure, published numerously. 
3 This table is a result of the impressing performance of Brazilian sports historians in researching and collecting dates and facts on the origins and development of Brazilian sports

Submission: $21 / 12 / 2018$

Approbation: 18/07/2019

Contact:

Arbeitsbereich Sportpädagogik \& Sportgeschichte am Institut für Sportwissenschaft der Westfälischen Wilhelms-Universität zu Münster 48149 Münster, Horstmarer Landweg 62b 